\title{
Characterization and identification of human immortalized granulosa cells derived from ovarian follicular fluid
}

\author{
AI AI ${ }^{1,2}$, ZHENGYA TANG $^{3}$, YALI LIU ${ }^{2}$, SHA YU $^{2}$, BIN LI $^{2}, \mathrm{HE} \mathrm{HUANG}^{3}$, \\ XIANGSHENG WANG ${ }^{3}$, YILIN CAO ${ }^{1,3}$ and WENJIE ZHANG ${ }^{1,3}$ \\ ${ }^{1}$ Department of Plastic and Reconstructive Surgery, Shanghai Ninth People's Hospital, \\ Shanghai Jiao Tong University School of Medicine; ${ }^{2}$ Department of Assisted Reproduction, \\ Shanghai Ninth People's Hospital; ${ }^{3}$ Shanghai Key Laboratory of Tissue Engineering, \\ Shanghai 200011, P.R. China
}

Received October 15, 2018; Accepted June 13, 2019

DOI: $10.3892 /$ etm.2019.7802

\begin{abstract}
Follicular fluid serves a crucial role in follicular development and oocyte maturation. Increasing evidence indicates that follicular fluid is rich in proteins and functional cells. In addition to oocyte cells, follicular fluid contains granulosa, thecal and ovarian surface epithelial cells. Granulosa cells (GCs) represent the predominant somatic cell type of the ovarian follicle and are involved in steroidogenesis and folliculogenesis. However, the long-term culture of GCs in vitro remains challenging. The present study aimed to extend the culture of GCs in vitro. Human GCs were collected from the follicular fluid of patients included in an in vitro fertilization program and cultured in the presence of conditioned medium obtained from mouse embryonic fibroblasts. GCs were cultured for over a year and 130 passages, and the population doubling time was $\sim 22 \mathrm{~h}$. Cells presented epithelial-like morphology and a cobblestone-like appearance when they reached confluence. Flow cytometric analysis demonstrated that cells expressed CD29, CD166 and CD49f but not CD31, CD34, CD45, CD90, CD105 or CD13. Immunofluorescence staining revealed that cells expressed follicle stimulating hormone receptor, luteinizing hormone receptor and cytochrome P450 aromatase, which was confirmed by reverse transcription-quantitative
\end{abstract}

Correspondence to: Professor Yilin Cao or Dr Wenjie Zhang, Department of Plastic and Reconstructive Surgery, Shanghai Ninth People's Hospital, Shanghai Jiao Tong University School of Medicine, 639 Zhi Zao Ju Road, Shanghai 200011, P.R. China

E-mail: yilincao@yahoo.com

E-mail:wenjieboshi@aliyun.com

Abbreviations: AR, androgen receptor; CYP19A, cytochrome $\mathrm{P} 450$ aromatase; ER- $\alpha$, estrogen receptor- $\alpha$; ER- $\beta$, estrogen receptor- $\beta$; FSHR, follicle-stimulating hormone receptor; LHR, luteinizing hormone receptor; PR, progesterone receptor

Key words: granulosa cells, luteinizing granulosa cells, steroidogenesis, follicle-stimulating hormone receptor, luteinizing hormone receptor, aromatase polymerase chain reaction. In the presence of androstenedione, cells secreted estradiol. In addition, estradiol level was further stimulated by dibutyryl cAMP treatment. In addition, intracellular cAMP and progesterone expression levels were upregulated by follicle stimulating hormone and/or human chorionic gonadotropin. Furthermore, cells survived in severe combined immunodeficiency mice following intra-ovarian injection. Histological analysis revealed that certain cells formed follicle-like structures. The results from the present study suggested that immortalized GCs may be a useful tool for further research on GC and improve the clinical application of drugs such as follicle-stimulating hormone or human chorionic gonadotropin.

\section{Introduction}

The development of ovarian follicles begins with the proliferation of granulosa cells (GCs), which change shape from flat to cubical and from single- to multi-layered cells $(1,2)$. At the late stage of preantral follicle development, follicle-stimulating hormone receptor (FSHR) appears in GC membranes. The activity of GCs is regulated by follicle-stimulating hormone (FSH) and luteinizing hormone (LH) (3). The preovulatory follicle comprises follicular fluid, an oocyte, hundreds to thousands of GCs and two layers of surrounding theca cells. GCs of the preovulatory ovarian follicle represent a predominant somatic cell type of the ovarian follicle. GCs are responsible for the communication between the oocyte and the theca cells, which are regulated by the gonadotropins FSH and LH, produce estrogen and nurse the oocyte. Following ovulation, GCs become luteinized GCs, which produce large amounts of progesterone to support the corpus luteum and subsequent pregnancy (4).

Luteinized GCs have long been considered as terminally differentiated cells with a limited life span (5). Previous studies demonstrated that GCs present certain characteristics of stem cells (6-8). Lavranos et al (6) reported that bovine luteinized GCs are able to grow in colonies and retain the ultrastructural features of follicular GCs in an anchorage-independent culture system. Van Deerlin et al (7) revealed that luteinized GCs from a follicle are derived from a small number 
of stem cells. Furthermore, Lavranos et al (8) demonstrated that the telomerase activity in the ovary originated mainly from preovulatory GCs and not the ovarian follicle oocyte, which supported the hypothesis that GCs could originate from a stem cell population. Additional studies demonstrated that GCs possess a multipotent differentiation capacity. Bukovsky et al (9) reported that porcine preovulatory GCs can convert into neural stem cells and differentiate into neurons. In addition, Kossowska-Tomaszczuk et al (3) demonstrated that luteinized GCs cultured in vitro can differentiate into neurons, chondrocytes and osteoblasts. These studies confirmed the presence of granulosa stem cells in the ovary (10-13).

Culture and expanding granulosa stem cells in vitro may be useful for basic research and clinical applications; however, cultivating human GCs in vitro remains a major challenge. Several attempts have been made to prolong the lifespan of GCs in culture, although these methods had limited success. These attempts included creating a three-dimensional culture system (14), supplementing follicular fluid into culture media (15), or adding growth factors into culture media (3). Mouse embryonic fibroblasts (MEFs) usually serve as a feeder cell layer for mouse and human embryonic stem cell cultures and can provide a suitable environment containing growth factors, cytokines and allowing cell-cell interactions, which maintain cells in an undifferentiated state (16-18). MEF-conditioned culture medium may therefore be helpful to support the growth of GCs in vitro. To test this hypothesis, follicular fluid from infertile women who underwent oocyte retrieval during in vitro fertilization (IVF) was collected. Cells from the follicular fluid were cultured in the presence of MEF-conditioned medium. Immortalized ovarian GCs were purified following $>1$ year culture. In addition, the phenotypic and functional features of the GCs were characterized.

\section{Materials and methods}

Collection of follicular fluid cells. Follicular fluid cells were collected from 109 infertile women who underwent IVF at the Department of Assisted Reproduction of the Ninth People's Hospital of Shanghai Jiaotong University School of Medicine between March 2013 and December 2016. The study included women aged between 22 and 32 years with tubal, unexplained or male factors of infertility, and excluded women who had ovarian cyst or tumor. Patients were first treated with controlled ovarian stimulation drugs such as 150-225 IU human menotropin (Anhui Fengyuan Pharmaceutical Co., Ltd.), $10 \mathrm{mg}$ medroxyprogesterone acetate (Zhejiang Xianju Pharmaceutical Co., Ltd.) or $0.1 \mathrm{mg}$ triptorelin (Decapeptyl ${ }^{\circledR}$; Ferring Pharmaceuticals) per day for 7 to 10 days. Next, ovulation was triggered with $0.1 \mathrm{mg}$ triptorelin and/or 2,000-5,000 IU human chorionic gonadotropin (Lizhu Pharmaceutical Trading Co., Ltd.). After 34-38 h of trigger administration, all oocytes in follicles with diameters $>10 \mathrm{~mm}$ were retrieved by transvaginal ultrasound-guided aspiration (19).

Following the removal of the oocyte-corona-cumulus complexes, the fresh follicular fluid was centrifuged for $5 \mathrm{~min}$ at $524 \mathrm{x} \mathrm{g}$ and $4^{\circ} \mathrm{C}$. Next, the cell pellet was collected and washed three times with PBS. Following this step, cells were isolated by density gradient centrifugation with $2 \mathrm{ml}$ Percol (Santa Cruz Biotechnology, Inc.) for $30 \mathrm{~min}$ at 2,095 x g and $4^{\circ} \mathrm{C}$. Cells in the interphase layer were collected and washed three times with Dulbecco's-modified Eagle's medium (DMEM; Invitrogen; Thermo Fisher Scientific, Inc.). Cells were placed on $100-\mathrm{mm}^{2}$ tissue culture dishes in the presence of MEF-conditioned medium as described below. To obtain enough cells, follicular fluid from 5 to 10 patients was pooled into one primary cell culture.

The ovarian tissue sample was obtained from one female patient who underwent laparoscopic excision of dermoid cysts at the Department of Gynecology, Shanghai Ninth People's Hospital. The patient was 22 years old and the recruitment/collection date was February 2016.

The BMSCs were obtained from one male patient who suffered from femoral head necrosis and underwent BMSCs implantation procedures at the Department of Orthopedics, Shanghai Ninth People's Hospital. He was 23 years old and the recruitment/collection date was March 2016.

Human chondrocytes were obtained from a patient who underwent rhinoplasty procedures at the Department of Plastic and Reconstructive Surgery, Shanghai Ninth People's Hospital (20). She was a 27-year old female and the recruitment/collection date was April 2016.

Fresh follicle cells (FCs) were obtained from female patients who underwent IVF procedures at the Department of Assisted Reproduction, Shanghai Ninth People's Hospital. Their age distribution was between 24 and 32 years old (the median age was 29 years old). The date of recruitment/sample collection was between December 2015 and April 2016. The exclusion criteria were women with ovarian cysts or tumors.

The study was approved by the local Ethics Committee of the Ninth People's Hospital of Shanghai. All participants, including patients undergoing IVF, and patients from whom ovarian tissue samples, bone marrow mesenchymal stem cells (BMSCs), chondrocytes and fresh FCs were obtained, provided written informed consent.

Cell culture. Follicular fluid cells were cultured in a mixed culture medium that consisted of $70 \%$ basic culture medium and 30\% MEF-conditioned medium. The basic culture medium comprised DMEM containing $4.5 \mathrm{~g} / 1$ glucose (Gibco; Thermo Fisher Scientific, Inc.) and supplemented with $10 \%$ fetal calf serum (FCS; Gibco; Thermo Fisher Scientific, Inc.), $50 \mathrm{~g} / \mathrm{ml}$ penicillin/streptomycin (Gibco; Thermo Fisher Scientific,Inc.), $3 \mathrm{mmol} / \mathrm{l} \mathrm{L}$-glutamine (Sigma-Aldrich; Merck KGaA) and $10 \mathrm{mM} \beta$-mercaptoethanol (Sigma-Aldrich; Merck KGaA). Cells were seeded at a density of $1.5 \times 10^{6}$ cells $/ 100 \mathrm{~mm}^{2}$ bacterial-culture dish and incubated at $37^{\circ} \mathrm{C}$ and $5 \% \mathrm{CO}_{2}$. Medium was exchanged after $24 \mathrm{~h}$ and cells were passaged every 3-4 days. Images of primary passages 1, 2, 4, 50 and 99 were captured under an inverted light microscope (magnification, x100; Vert.A1; Zeiss GmbH).

The BMSCs were suspended in $\alpha$-MEM (alpha-Minimum Essential Medium) containing 10\% fetal bovine serum (Hyclone; GE Healthcare Life Sciences), $50 \mathrm{mg} / \mathrm{ml}$ sodium ascorbate (Sigma-Aldrich; Merck KGaA), antibiotic/antimycotic and $10^{-8} \mathrm{M}$ dexamethasone (Sigma-Aldrich; Merck KGaA) and then seeded at a density of $1.5 \times 10^{6}$ cells $/ 100 \mathrm{~mm}^{2}$ bacterial-culture dish and incubated at $37^{\circ} \mathrm{C}$ and $5 \% \mathrm{CO}_{2}$. Medium was exchanged every 2-3 days. BMSCs were passaged every 5-7 days.

Fresh FCs were cultured in DMEM containing $4.5 \mathrm{~g} / 1$ glucose (Gibco; Thermo Fisher Scientific, Inc.) and 
supplemented with $10 \%$ fetal calf serum (FCS; Gibco; Thermo Fisher Scientific, Inc.), $50 \mathrm{~g} / \mathrm{ml}$ penicillin/streptomycin (Gibco; Thermo Fisher Scientific, Inc.). Medium was exchanged after $24 \mathrm{~h}$ and changed every 2 days.

MEFs were prepared in our laboratory as previously described (21). Briefly, MEFs were seeded at a density of $1 \times 10^{6}$ cells $/ 100 \mathrm{~mm}^{2}$ bacterial-culture dish and then cultured with DMEM medium supplemented with $10 \%$ FBS and $50 \mathrm{~g} / \mathrm{ml}$ penicillin/streptomycin at $37^{\circ} \mathrm{C}$ and $5 \% \mathrm{CO}_{2}$. The MEFs were passaged every 3-4 days. From passages 2-5, the supernatant of MEFs was collected and centrifuged at $524 \mathrm{x} \mathrm{g}$ at $37^{\circ} \mathrm{C}$ for $5 \mathrm{~min}$ every $48 \mathrm{~h}$ to produce conditioned medium. The conditioned medium was then sterilized with $0.22-\mu \mathrm{m}$ filters and frozen at $-20^{\circ} \mathrm{C}$ until further use. Cells, including follicular fluid cells, BMSCs and MEFs, were passaged using $0.1 \%$ trypsin/EDTA (Invitrogen; Thermo Fisher Scientific, Inc.) once they reached $80 \%$ confluence.

Growth curve of human GCs. Cell counting was performed from passage 4 up to passage 34 with a hemocytometer. The population doubling time (DT) was determined according to the following formula: DT= $\mathrm{t} x[\lg 2 /(\operatorname{lgNt}-\lg \mathrm{N} 0)](15)$ where ' $t$ ' is the time between cell seeding and harvesting, ' $N 0$ ' is the number of cells seeded and ' $\mathrm{Nt}$ ' is the number of cells following culture. This determination was performed in three dishes for each experiment.

Colony formation assay. Colony formation assays were performed as previously described (22). Briefly, cells at passage 8 were seeded at the density of 100 single cells per plate in triplicate. Following 20 days culture, cells were stained with crystal violet and the number of clones was counted by naked eye. The images of a large colony derived from a single cell was observed on days 1, 2, 3, 6, 12 and 15 under an inverted light microscope (magnification, $\mathrm{x} 40$; Vert.A1; Zeiss $\mathrm{GmbH}$ ). The colony formation efficiency was calculated from three repeated experiments. The efficiency was calculated as mean \pm SD.

Flow cytometric analysis. Cells at passages 10 and 30 were harvested for flow cytometric analysis. Prior to staining with the fluorescence conjugated antibodies, cells were incubated with $2.5 \mu \mathrm{g} /$ test of Human BD Fc BlockTM at $4^{\circ} \mathrm{C}$ for $10 \mathrm{~min}$ (cat. no. 564219). Cells were incubated with phycoerythrin-conjugated CD13 (cat. no. 560998; 1:200 dilution), CD29 (cat. no. 556049; 1:200 dilution), CD31 (cat. no. 554061; 1:200 dilution), CD34 (cat. no. 550761; 1:200 dilution), CD45 (cat. no. 557055; 1:200 dilution), CD49f (cat. no. 555736; 1:200 dilution), CD90 (cat. no. 555596; 1:200 dilution), CD105 (cat. no. 560839; 1:200 dilution), CD166 (cat. no. 560903; 1:200 dilution) and human leukocyte antigen-ABC (HLA-ABC) antibodies (cat. no. 560168; 1:200 dilution) for 30 min at $4^{\circ} \mathrm{C}$ (antibodies were all from BD Biosciences). Cells were washed three times with PBS and analyzed with a flow cytometer (Epics Altra; Beckman Coulter, Inc.). Flow cytometry data were analyzed with CXP software (EXPO32 v1.2; Beckman Coulter, Inc.).

Immunofluorescence staining. FCs and BMSc at passages 10 and 60 were fixed with $4 \%$ cold paraformaldehyde (Sigma-Aldrich; Merck KGaA) in PBS for $15 \mathrm{~min}$ at $4^{\circ} \mathrm{C}$ and permeabilized with $0.25 \%$ Triton X-100 (Sigma-Aldrich; Merck KGaA) in PBS for 10 min. Fixed cells were blocked for $30 \mathrm{~min}$ at $37^{\circ} \mathrm{C}$ with PBS containing $1 \%$ bovine serum albumin (BSA; Sigma-Aldrich; Merck KGaA) and $10 \%$ goat serum (Sigma-Aldrich; Merck KGaA), and incubated with goat anti-human FSHR (cat. no. sc7798; 1:100;), rabbit anti-human luteinizing hormone receptor (LHR; cat. no. sc25828; 1:100;) or mouse anti-human cytochrome P450 aromatase (CYP19A; cat. no. sc374176; 1:100; all from Santa Cruz Biotechnology, Inc.) antibodies at $4^{\circ} \mathrm{C}$ overnight. Cells were then incubated with secondary antibodies labelled with Alexa Fluor 555 for $30 \mathrm{~min}$ at $37^{\circ} \mathrm{C}$. Specifically, the donkey anti-goat $\mathrm{IgG}$ (1:1,000; cat no: A21432) was used for binding the primary antibody goat anti-human FSHR, goat anti-rabbit $\operatorname{IgG}(1: 1,000$; cat no: A21428) was used for binding the primary antibody rabbit anti-human luteinizing hormone receptor and goat anti-mouse IgG (1:1,000; cat no: A21422) were used for binding the primary antibody mouse anti-human cytochrome P450 aromatase CYP19A. All secondary antibodies were purchased form Invitrogen (Thermo Fisher Scientific, Inc.), Nuclei were counterstained with DAPI for $5 \mathrm{~min}$ and $25^{\circ} \mathrm{C}$ (Invitrogen; Thermo Fisher Scientific, Inc.). Human BMSCs, which were isolated and expanded as previously described (23), served as a negative control.

Reverse transcription (RT)-semi-quantitative PCR. Human ovarian tissue and FCs served as positive controls while chondrocytes served as negative control. Total RNA was extracted from ovarian tissue, FCs, GCs at passage 10 or passage 60 and chondrocytes using TRIzol ${ }^{\circledR}$ (Invitrogen; Thermo Fisher Scientific, Inc.). Ovarian tissue was dissected into $5 \times 5 \times 5 \mathrm{~mm}$ samples and quickly placed into the sterile culture tube containing TRIzol ${ }^{\circledR}(1.5 \mathrm{ml})$ for $15 \mathrm{~min}$ then RNA was extracted from the homogenized solution. RT-PCR was performed using an RT-PCR kit (TaKaRa Taq ${ }^{\mathrm{TM}}$ and Reverse Transcriptase XL (AMV); Takara Bio, Inc.) according to the manufacturer's instructions. The temperature protocol for RT was as follow: $30^{\circ} \mathrm{C}$ for $10 \mathrm{~min}, 42^{\circ} \mathrm{C}$ for $60 \mathrm{~min}, 99^{\circ} \mathrm{C}$ for $5 \mathrm{~min}$ and $5^{\circ} \mathrm{C}$ for $5 \mathrm{~min}$. The thermocycling conditions for PCR was as follow: $95^{\circ} \mathrm{C}$ for $3 \mathrm{~min}, 95^{\circ} \mathrm{C}$ for $30 \mathrm{sec}, 60-62^{\circ} \mathrm{C}$ for $30 \mathrm{sec}, 72^{\circ} \mathrm{C}$ for $30 \mathrm{sec}$ and $29-34$ cycles, $72^{\circ} \mathrm{C}$ for $10 \mathrm{~min}$. The sequences of the analyzed genes were searched in the GenBank from the National Centre for Biotechnology Information (www. ncbi.nlm.nih.gov/genbank). Primers were synthesized by Sangon Biotech Co., Ltd. The sequences of the primers are listed in Table I. DNA polymerase used was TaKaRa Taq ${ }^{\mathrm{TM}}$ (Takara Bio, Inc.) and reverse transcriptase used was Reverse Transcriptase XL (AMV) (Takara Bio, Inc.). In the procedure of semi-quantitative PCR, the thermocycling conditions were as following: FSHR at $60^{\circ} \mathrm{C}$ for 34 cycles; LHR at $60^{\circ} \mathrm{C}$ for 34 cycles; CYP19A at $62^{\circ} \mathrm{C}$ for 34 cycles; estrogen receptor- $\alpha$ $(\mathrm{ER}-\alpha), 60^{\circ} \mathrm{C}, 29$ cycles; estrogen receptor- $\beta$ (ER- $\left.\beta\right), 60^{\circ} \mathrm{C}$, 29 cycles; progesterone receptor (PR) at $60^{\circ} \mathrm{C}$ for 29 cycles and androgen receptor (AR) at $60^{\circ} \mathrm{C}$ for 29 cycles. The amplified products were separated on $1.2 \%$ agarose gels and visualized with ethidium bromide (Sigma-Aldrich; Merck KGaA).

Measurement of intracellular cyclic adenosinemonophosphate (cAMP). Intracellular cAMP following stimulation with recombinant human FSH (rhFSH; Gonal- $\mathrm{f}^{\circledR}$; 
Table I. Primer sequences used for reverse-transcription-semi-quantitative PCR.

\begin{tabular}{llc}
\hline Name & \multicolumn{1}{c}{ Primers (5'-3') } & Size (bp) \\
\hline FSHR & & 248 \\
Forward & GCGGAACCCCAACATCGTGTC & \\
Reverse & TGAAGAAATCTCTGCGAAAGT & \\
LHR & & 256 \\
Forward & TCAATGTGGTGGCCTTCTTCATA & \\
Reverse & TTGGCACAAGAATTGATGATGG & \\
& GATA & \\
CYP19A & & 396 \\
Forward & CCATAAAGACCCGATTCCACCA & \\
Reverse & GCTGAGGCATAAATCGACAGAC & \\
ER- $\alpha$ & & 207 \\
Forward & GAGAGGTCATTGGTTATAGAGA & \\
Reverse & CCGAGTCACATCAGTAATAGT & \\
ER- $\beta$ & & 257 \\
Forward & TTCTCCTTCCTCCTACAACT & \\
Reverse & ATGTGATAACTGGCGATGG & \\
PR & & 248 \\
Forward & GGGATGAAGCATCAGGCTGT & \\
Reverse & AGCATCCAGTGCTCTCACAA & \\
AR & & 246 \\
Forward & GTGCTGGACAGCACAACAAC & \\
Reverse & GATCAGGGGCGAAGTAGAGC & \\
$\beta$-actin & & \\
Forward & GGACGACATGGAGGAAAT & \\
Reverse & GATAGCACAGCCTGGATA & \\
\hline AR, & & \\
& & \\
& &
\end{tabular}

AR, androgen receptor; bp, base pair; CYP19A, cytochrome P450 aromatase; ER- $\alpha$, estrogen receptor- $\alpha$; ER- $\beta$, estrogen receptor- $\beta$; FSHR, follicle-stimulating hormone receptor; LHR, luteinizing hormone receptor; PR, progesterone receptor.

Merck KGaA) and human chorionic gonadotropin (HCG, Lizhu Pharmaceutical Trading Co., Ltd.) was measured with an ELISA kit (Deco; DECO0254; http://www.seranachina. $\mathrm{com} / \mathrm{sh}$ _product.asp?id=826). The biological potency of rhFSH was $900 \mathrm{IU} / 1.5 \mathrm{ml}(100 \mathrm{ng} / \mathrm{ml})$. Cells at passage 13 were serum starved $12 \mathrm{~h}$ prior to the experiments and cells that reached confluence in six-well plates $\left(\right.$ Falcon $^{\mathrm{TM}}$; Thermo Fisher Scientific, Inc.) were transferred into medium (it was called a cAMP basic medium, in order to distinguish with medium containing rhFSH or HCG.) containing $1.0 \%$ (w/v) BSA (Sigma-Aldrich; Merck KGaA), $0.5 \mathrm{mM}$ 3-isobutyl-1-methylxanthine (Sigma-Aldrich; Merck KGaA) and $10^{-5} \mathrm{M}$ forskolin (Sigma-Aldrich; Merck KGaA). The cells were further cultured for $3 \mathrm{~h}$ in the presence or absence of $5 \mathrm{IU} / \mathrm{ml} \mathrm{rhFSH}, 100 \mathrm{IU} / \mathrm{ml} \mathrm{HCG}$ or $5 \mathrm{IU} / \mathrm{ml} \mathrm{rhFSH}+100 \mathrm{IU} / \mathrm{ml}$ HCG. For the measurement of intracellular cAMP, cells were washed three times with $200 \mu \mathrm{l}$ PBS. Freeze-thaw cycles $\left(-80^{\circ} \mathrm{C}\right.$ for $30 \mathrm{~min}$ then $37^{\circ} \mathrm{C}$ for $20 \mathrm{~min}$ ) were repeated six times and cells were lysed and released their intracellular components.
Following centrifugation at $931 \mathrm{x} \mathrm{g}$ and $4^{\circ} \mathrm{C}$ for $5 \mathrm{~min}$, cAMP in the supernatant was measured by ELISA according to the manufacturer's protocol. All experiments were conducted in triplicate.

Measurement of the secreted steroid content in cell medium. To measure the concentrations of estradiol and progesterone in the medium, cells were cultured in DMEM containing $5 \%$ charcoal-stripped FCS (GeneTex, Inc.) for $24 \mathrm{~h}$ at $37^{\circ} \mathrm{C}$. Subsequently, cells were treated with $10 \mu \mathrm{M}$ androstenedione (4-androstene-3,17-dione; $\mathrm{A}_{2}$; Jinchun Biochem Inc., Shanghai, China) and stimulated with $5 \mathrm{IU} / \mathrm{ml} \mathrm{rhFSH}, 100 \mathrm{IU} / \mathrm{ml} \mathrm{HCG}$, $10^{-4} \mathrm{M}$ dibutyryl cAMP [ $\mathrm{Bu}_{2} \mathrm{cAMP}$; Enzo Life Sciences] or $10^{-5} \mathrm{M}$ forskolin for $48 \mathrm{~h}$. The estradiol and progesterone levels in the culture medium were determined with the chemiluminescent immunoassay i2000SR (ARCHITECT ${ }^{\circledR}$, Abbott Pharmaceutical Co. Ltd.). All experiments were conducted in triplicate.

Cell labeling. Cells at passage 8 were labelled by transfection with an enhanced green fluorescent protein (eGFP) sequence using a lentivirus vector (pNL-EGFP/CMV/WPREdU3; SunBio, Inc.; http://www.sbo-bio.com.cn) according to the manufacturer's protocol. The cells at passages 8 were seeded into a 24 -well plate at a density of $3.6 \times 10^{4}$ cells $/ \mathrm{ml}$. After incubation for $24 \mathrm{~h}$, the culture medium was removed, and the virus-containing medium were added into the cells at a multiplicity of infection (MOI) of 10. A total of $1.8 \mu \mathrm{l}$ of $2 \mathrm{X} 10^{5} \mathrm{TU} / \mu 1$ lentiviral particles for transfecting $3.6 \times 10^{4}$ cells, so the MOI was calculated as 10 . Following 48 -h of transfection, puromycin selection was performed. The viral solution was replaced with $1 \mathrm{~mL}$ DMEM medium with $1 \mu 1$ Puromycin ( $2 \mathrm{mg} / \mathrm{ml}$, SunBio, Inc.). Following incubation for $24 \mathrm{~h}$, puromycin-containing medium was replaced with DMEM medium. The labeling efficiency was directly observed under a fluorescence inverted microscope (Vert.A1; Zeiss GmbH).

Intra-ovarian transplantation. eGFP-labelled cells were suspended in DMEM at the density of $1 \times 10^{7}$ cells $/ \mathrm{ml}$. A total of $1 \times 10^{5}$ cells were injected into the right ovary of 227 -week-old female severe combined immunodeficiency (SCID) mice (Shanghai Sipuer-Bik Laboratory Animal Co., Ltd.) using a microinjector (Microsyringe). Mice were about 15-20 g and were housed at $21 \pm 2^{\circ} \mathrm{C}$ in a humidified atmosphere (40-70\%) with 12-h light/dark cycles with free access to food and water. Meanwhile, $1 \times 10^{5}$ cells were subcutaneously injected into two sides of the dorsal region of 4 SCID mice and $1 \times 10^{5}$ cells were peritoneal cavity of 4 SCID mice. Animals were sacrificed by cervical dislocation. Ovarian tissues were harvested at 8 weeks post-transplantation. Ovarian tissues were fixed in $4 \%$ paraformaldehyde for $24 \mathrm{~h}$ at room temperature, then placed in freezing microtome, embedded at $-25^{\circ} \mathrm{C}$ with an OCT embedding agent, the frozen section thickness was $6 \mu \mathrm{m}$. Fresh-frozen sections were used. The sections were observed under the fluorescence inverted microscope (Vert.A1; Zeiss $\mathrm{GmbH})$. For H\&E staining, fresh-frozen sections were first fixed with $10 \%$ neutral buffered formalin for $1 \mathrm{~min}$ at room temperature and then dehydrated in an alcohol series, which was as follow: $100 \%$ alcohol for $5 \mathrm{~min}, 95 \%$ alcohol for $5 \mathrm{~min}$, $85 \%$ alcohol for $3 \mathrm{~min}$ and $75 \%$ alcohol for $2 \mathrm{~min}$. Next, the sections were stained with Harris hematoxylin solution for 
A

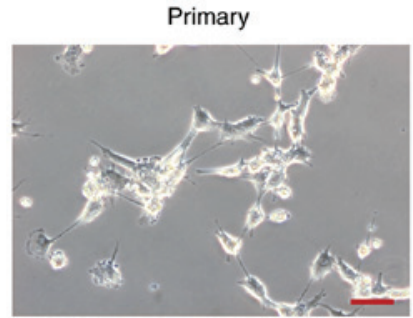

Passage 4

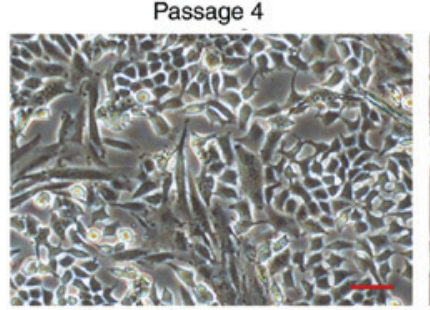

Passage 1

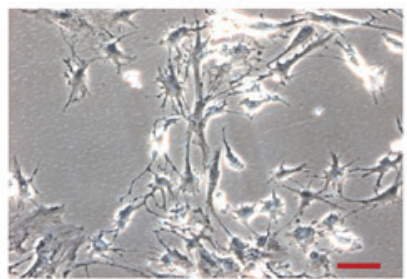

Passage 50

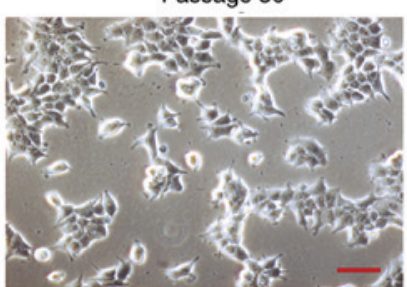

Passage 2

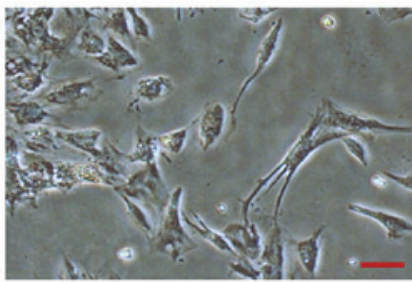

Passage 99

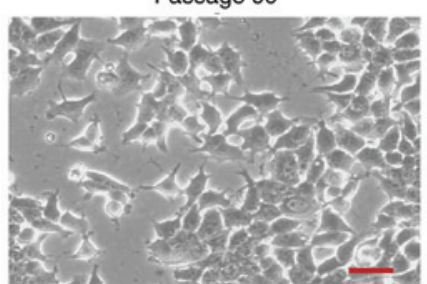

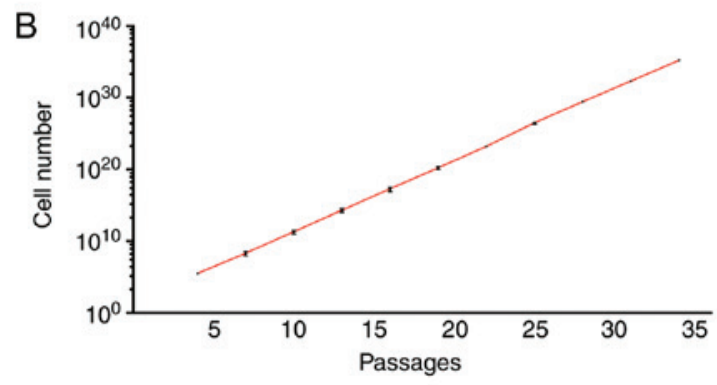

C

Day 1

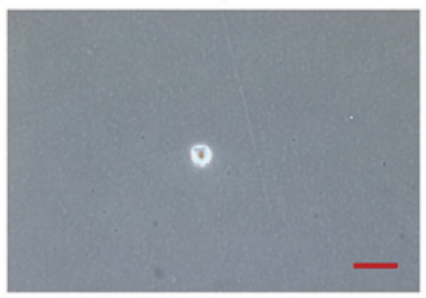

Day 6

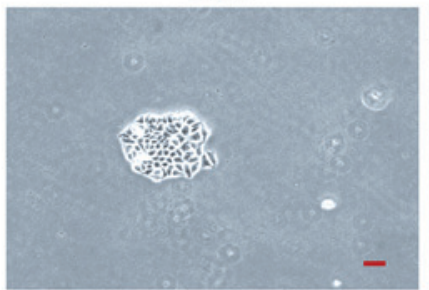

Day 2

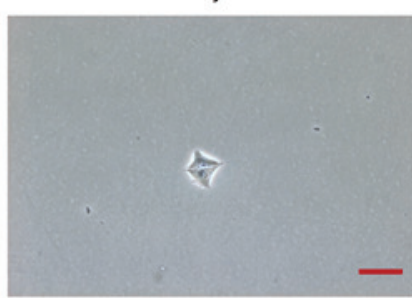

Day 12

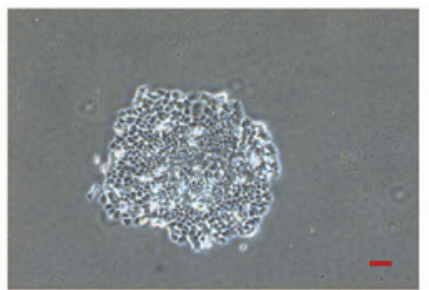

Day 3

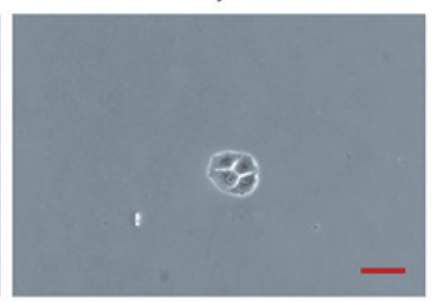

Day 15

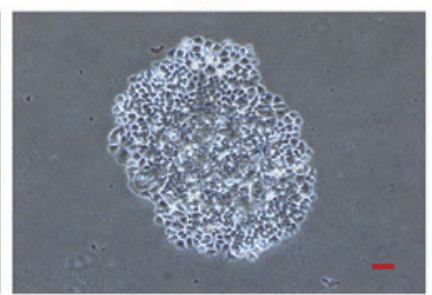

Figure 1. Cell morphology and proliferation. (A) Shape of follicular fluid-derived human GCs expanded with mouse embryonic fibroblasts-conditioned medium. From passage 4, a small group of epithelial-like cells surrounded by spindle-shaped fibroblastic cells were observed. Epithelial-like cells were observed with no obvious morphological changes at passage 99. (B) Growth curve of follicular fluid-derived human GCs. Data are presented as the mean \pm standard deviation. (C) Colony formation of follicular fluid-derived human GCs. Scale bars, $100 \mu \mathrm{m}$. GCs, granulosa cells.

$8 \mathrm{~min}$ and washed under running tap water for $1 \mathrm{~min}$. Following that, the sections were counter-stained with DAPI for $5 \mathrm{~min}$ at room temperature. Finally, sections were observed under a light microscope (magnification, x200; Nikon, ECLIPSE Ni-E).

Statistical analysis. SPSS software (ver. 23.0, IBM Corp.) was used to analyze data. Data are presented as the mean \pm standard deviation. One-way ANOVA was used to compare data among different groups, and Dunnett's and Tukey's post hoc tests were used to perform multiple comparisons between groups. $\mathrm{P}<0.05$ was considered to indicate a statistically significant difference.

\section{Results}

Human GCs cultured in vitro. The morphological changes of the GCs in culture are presented in Fig. 1A. Cells with different morphologies were observed during early passages. From passage 4, a small group of epithelial-like cells surrounded by spindle-shaped fibroblastic cells was observed to proliferate rapidly. The number of epithelial-like cells increased in the following passages along with a decrease in fibroblastic cells. From passage 8, a uniform epithelial-like cell population was observed (data not shown). Cells were passaged every three days and presented a cobblestone-like appearance when they 

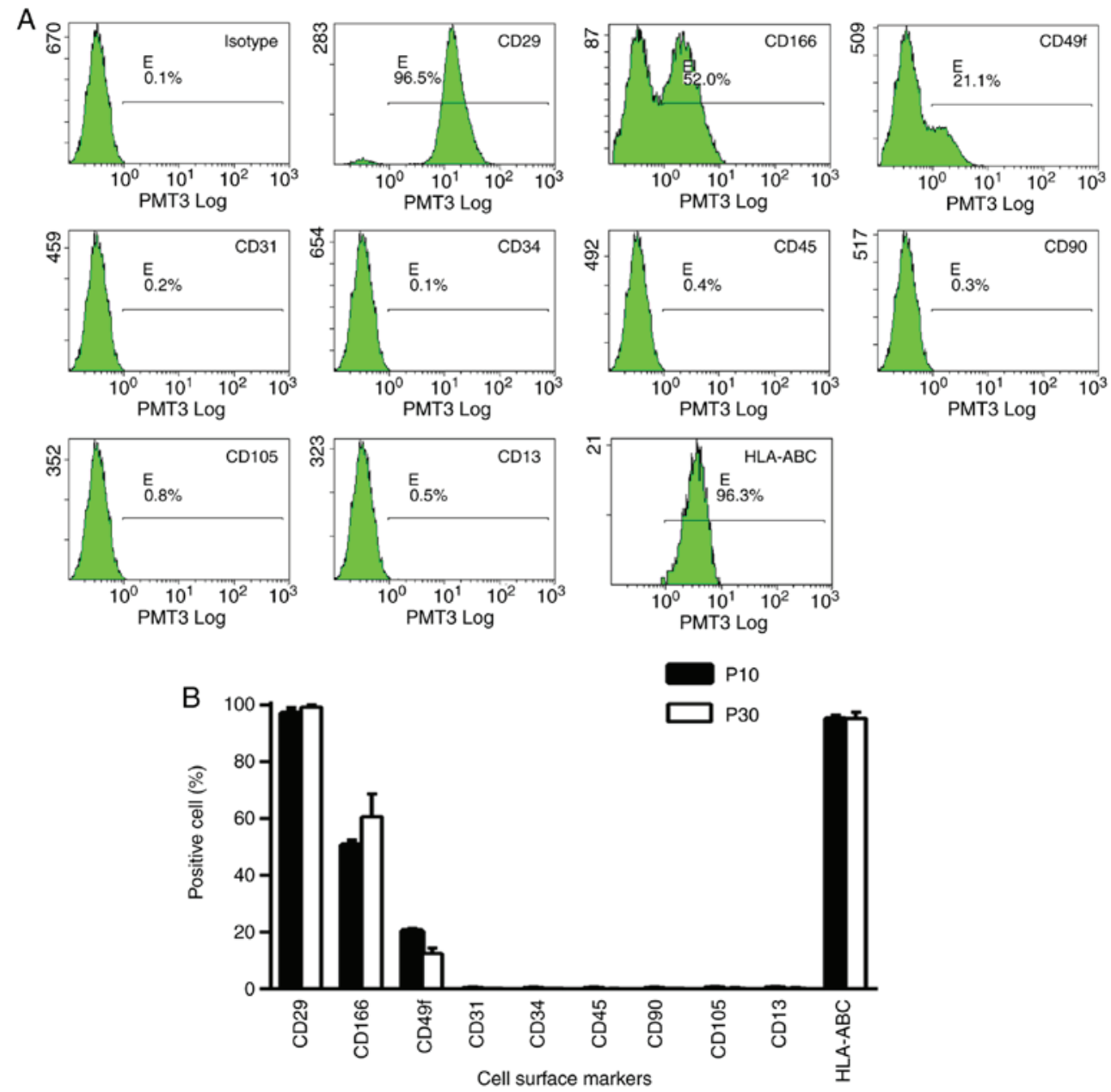

Figure 2. Cell surface marker expression profiles. (A) Representative histograms of cell surface marker expression of follicular fluid-derived human GCs at P10 analyzed by flow cytometry. (B) Statistical analyses of cell surface marker expression in the P10 and P30 follicular fluid-derived human GCs. Data are presented as the mean \pm standard deviation from three independent experiments. GCs, granulosa cells; HLA-ABC, human leukocyte antigen-ABC; , passage.

reached confluence (data not shown). No notable morphological changes were observed during the following passages. Images of primary, passages 1,2, 4, 50 and 99 were captured under an inverted light microscope (magnification, x100). Out of 20 experiments, cells died eventually in 19 experiments. Only within one culture, a group of cells were able to proliferate and continue to grow for up to 130 passages. Images of primary, passages 1, 2, 4, 50 and 99 were captured under an inverted light microscope. The GCs growth curve between passages 4 and 34 is presented in Fig. 1B. Cell proliferation was stable and the average doubling time was $\sim 22 \mathrm{~h}$. To further test the cell proliferation capacity, colony formation assays were performed at passage 8 . The formation of a large colony derived from a single cell was observed during the first 15 days of culture (Fig. 1C). Following seeding of 100 cells, 57, 53 and 59 clones were observed after 20 days of culturing in three repeated experiments (data not shown). The colony formation efficiency was calculated as $56.3 \pm 1.8 \%$.

Surface marker expression profile. Expression profile of cell surface markers was determined at passages 10 and 30 by flow cytometry (Fig. 2). Mouse IgG1 was used as an isotype. Cells expressed mesenchymal cell markers, including CD29, CD166, CD49f and HLA-ABC but did not express hematopoietic cell markers, including CD13, CD31, CD34, CD45, CD90 and CD105. The expression profile was stable and no significant difference was observed between cells at passages 10 and 30 .

Expression of FSHR, LHR, CYP19A, estrogen receptor $(E R)-\alpha, E R-\beta$, progesterone receptor $(P R)$ and androgen receptor $(A R)$. To further confirm cell identity, the expression of FSHR, LHR and CYP19A were analyzed at passages 10 and 60 by immunofluorescence staining. As presented in Fig. 3A, GCs in P10, 60 and FCs were positive for FSHR, LHR, and CYP19A whilst BMSCs were negative for FSHR, LHR, and CYP19A. Furthermore, the expression of FSHR, LHR, CYP19A, ER- $\alpha$, ER- $\beta$, PR and AR was confirmed by RT-PCR analysis (Fig. 3B). FSHR, LHR and CYP19A were expressed in GCs P10, 60, FCs and ovary tissue but not in mock and chondrocytes. ER- $\alpha$, ER- $\beta$, PR and AR were expressed in GCs P10, 60, FCs, ovary tissue and chondrocytes but not in mock.

Intracellular cAMP accumulation following rhFSH and HCG stimulation. Intracellular cAMP accumulation was measured following 3-h stimulation with $5 \mathrm{IU} / \mathrm{ml} \mathrm{rhFSH}, 100 \mathrm{IU} / \mathrm{ml}$ HCG or $5 \mathrm{IU} / \mathrm{ml} \mathrm{rhFSH}+100 \mathrm{IU} / \mathrm{ml} \mathrm{HCG}$. Intracellular cAMP levels were significantly increased following rhFSH and/or HCG stimulation compared with untreated cells (Fig. 4A). 
A
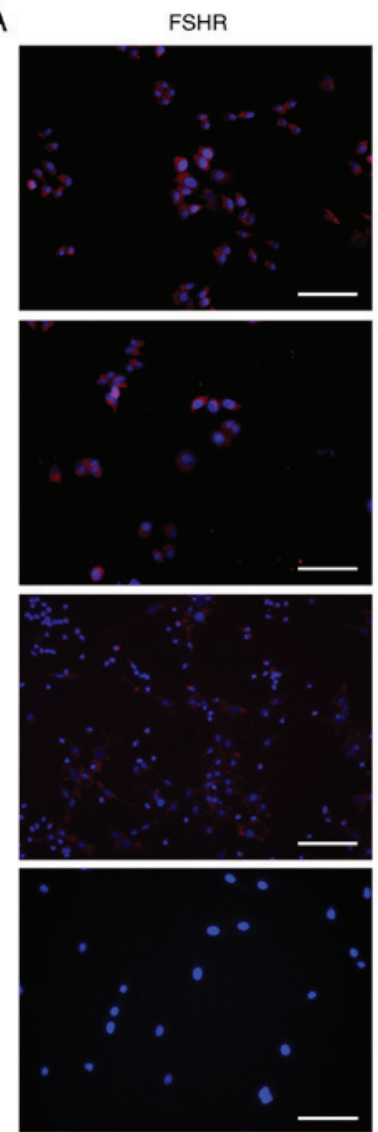

LHR
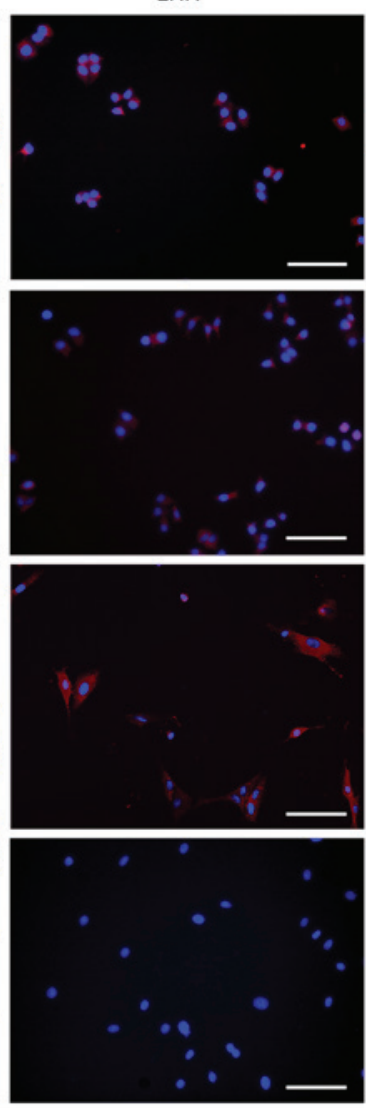
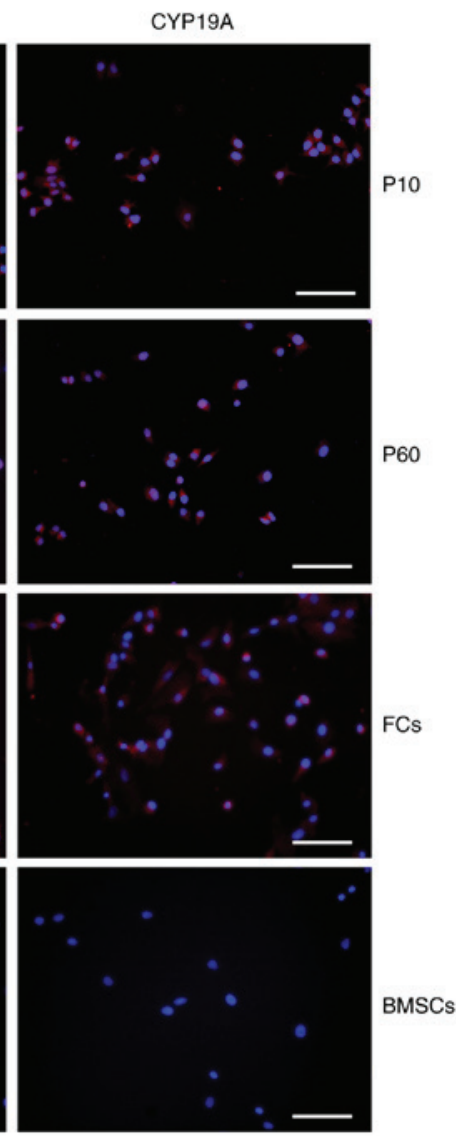

Chonc

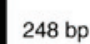

256 bp

396 bp

207 bp

257 bp

248 bp

246 bp

185 bp

Figure 3. Expression of FSHR, LHR, CYP19A, ER- $\alpha$, ER- $\beta$, PR and AR. (A) Immunofluorescence staining for FSHR (red), LHR (red) and CYP19A (red) in follicular fluid-derived human GCs at P10, follicular fluid-derived human GCs at P60, human FCs and human BMSCs. Cell nuclei (blue) were counterstained with DAPI. Scale bars, $200 \mu \mathrm{m}$. (B) Reverse transcription-semi-quantitative polymerase chain reaction analyses of reproduction-associated receptor genes in GCs at P10 and P60, ovary tissue, FCs and chondrocytes. $\beta$-actin was used as the internal control. AR, androgen receptor; BMSCs, bone marrow mesenchymal stem cells; Chonc, human chondrocytes; CYP19A, cytochrome P450 aromatase; ER- $\alpha$, estrogen receptor- $\alpha$; ER- $\beta$, estrogen receptor- $\beta$; FCs, human follicle cells; FSHR, follicle-stimulating hormone receptor; GCs, granulosa cells; LHR, luteinizing hormone receptor; Mock, control; Ovary, human ovarian tissue; P10, follicular fluid-derived human GCs at passage 10; P60, follicular fluid-derived human GCs at passage 60; PR, progesterone receptor.

Steroidogenic activities of GCs in vitro. The steroidogenic activities of GCs were evaluated by measuring the estradiol and progesterone concentrations in the culture medium. The results revealed detectable levels of basal secretion of estradiol and progesterone in the medium. Following $48 \mathrm{~h}$ of treatment with $\mathrm{A}_{2}$, estradiol level in the medium was significantly increased, No additional changes were observed when cells were co-stimulated with $\mathrm{rhFSH} / \mathrm{HCG} /$ forskolin. However, estradiol level was significantly increased following cell co-stimulation with $\mathrm{A}_{2}$ and $\mathrm{Bu}_{2} \mathrm{cAMP}$ (Fig. 4B). Furthermore, after $48 \mathrm{~h}$ of culturing, the levels of progesterone in medium significantly increased following the treatment with rhFSH and/or HCG in the presence of A2. But there was no difference when cells were treated with forskolin, Bu2cAMP combined with A2 or sole A2 administration (Fig. 4C).

Cell survival in SCID mice. Prior to cell transplantation, cells were transfected with an eGFP sequence using a lentivirus vector. Almost all cells expressed eGFP following eGFP transfection and puromycin selection (Fig. 5A). Cells were 

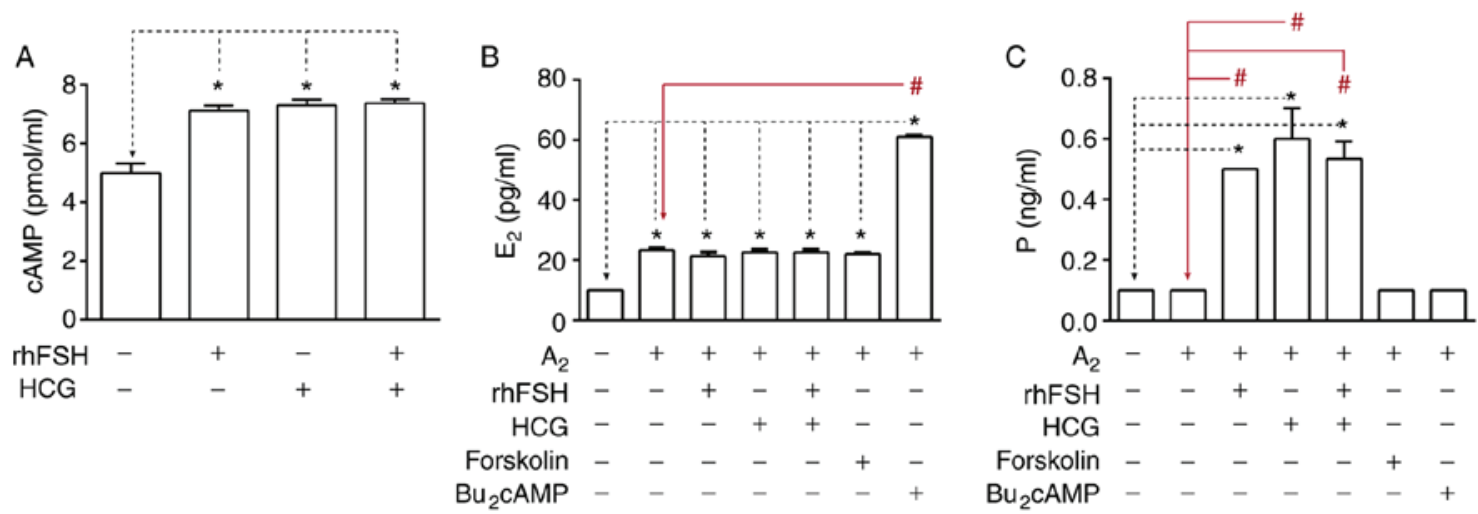

Figure 4. Production of cAMP, estradiol and progesterone. (A) Production of cAMP. cAMP contents secreted from FSH-stimulated and/or HCG-stimulated cells were significantly higher than those from non-stimulated cells. Concentrations of (B) estradiol and (C) progesterone in the culture medium. The experiments were repeated three times. In Fig. $4 \mathrm{~B}$ and $\mathrm{C}$, the standard deviation was 0 in some groups. ${ }^{~} \mathrm{P}<0.001 \mathrm{vs}$. control; ${ }^{*} \mathrm{P}<0.001 \mathrm{vs}$. control $+\mathrm{A}_{2}$. Bu $\mathrm{Bu}_{2} \mathrm{c} \mathrm{AMP}$ dibutyryl-cAMP; A2, 4-Androstene-3, 17-dione; F, forskolin; rhFSH, recombinant human FSH; GCs, granulosa cells; HCG, human chorionic gonadotropin.
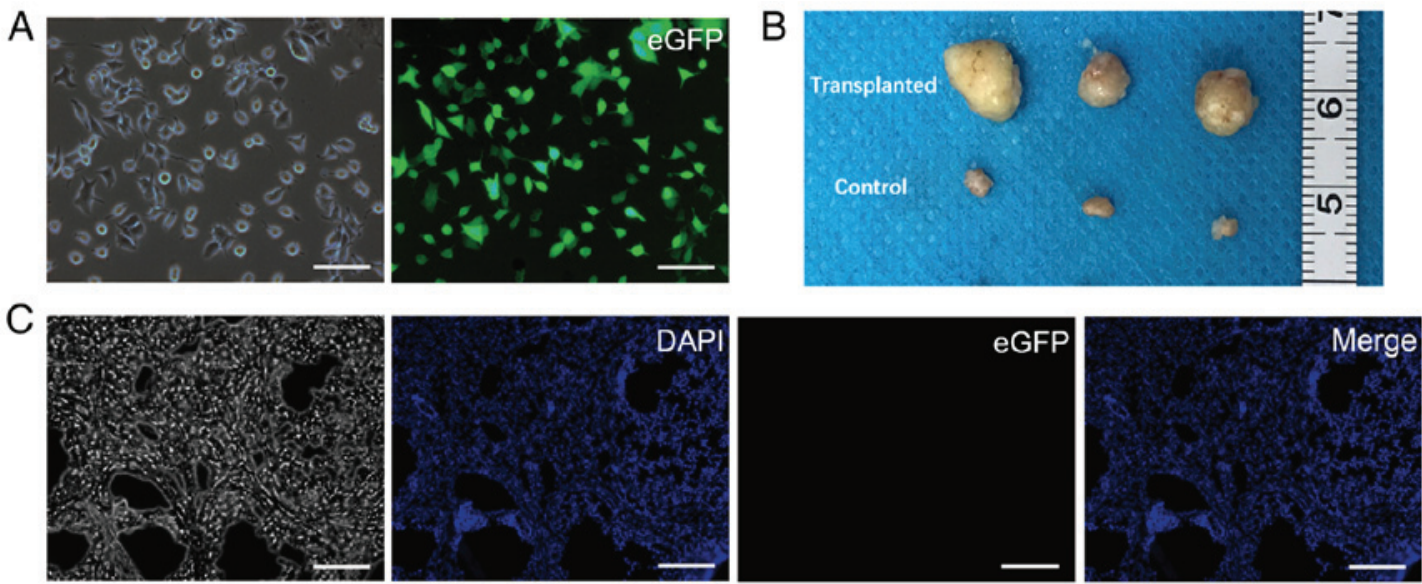

은
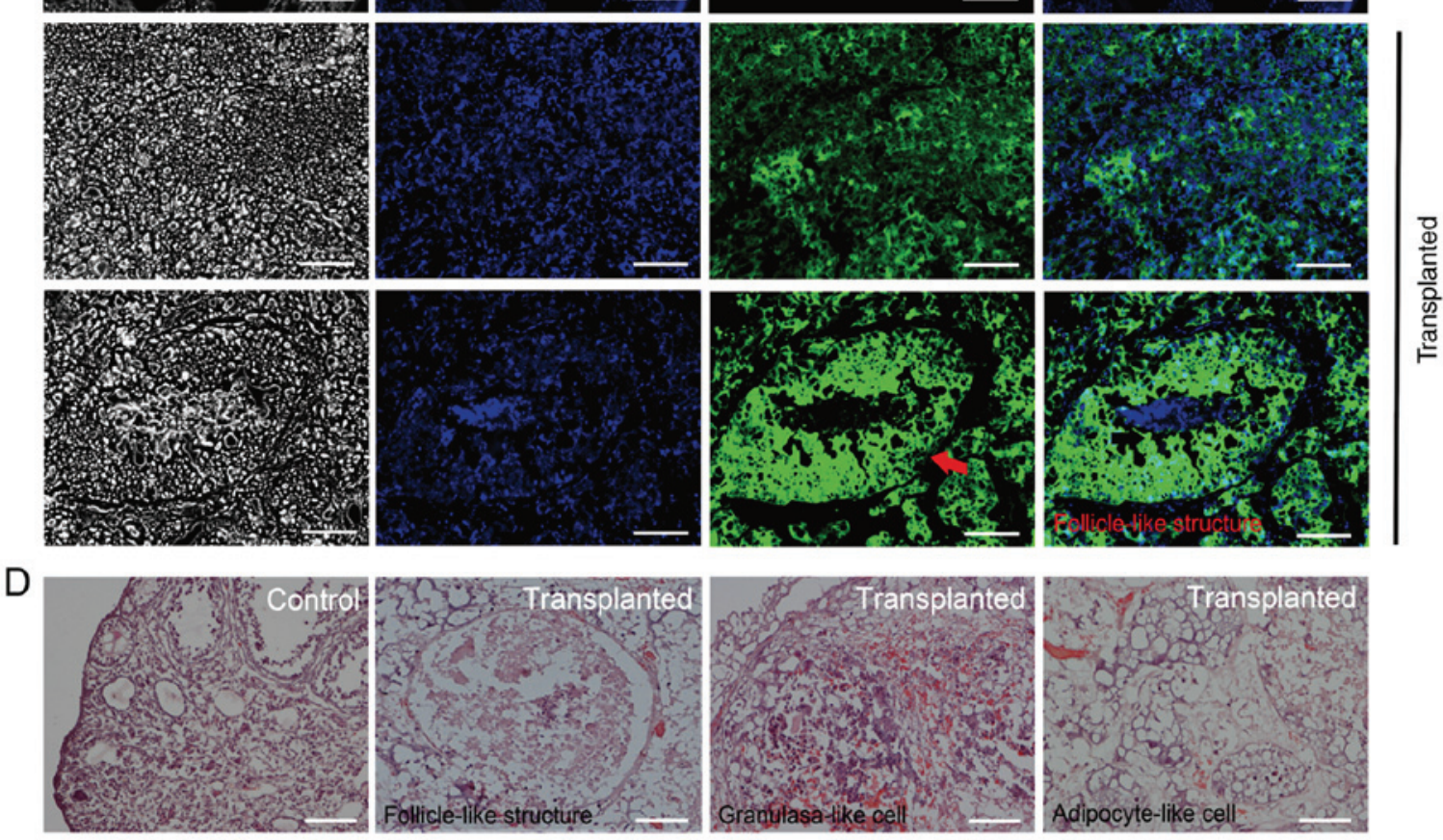

Figure 5. Ovaries of SCID mice 8 weeks following transplantation with eGFP-labelled cells. (A) Follicular fluid-derived human GCs were transfected with eGFP. Left image demonstrates GCs transfected with eGFP under white light, the right image was GCs transfected with eGFP under fluorescence. Almost all cells expressed eGFP following transfection with eGFP. Scale bars, $200 \mu \mathrm{m}$. (B) Murine ovaries 8 weeks following cell transplantation, the untransplanted ovaries were used as the control group. (C) Transplanted ovaries under fluorescence inverted microscope. The left black/white images were captured under white light. Red arrow, follicle-like structure in the transplanted ovary. Scale bars, $200 \mu \mathrm{m}$. (D) Follicle-like structures, granulosa-like cells and adipocyte-like cells in the transplanted ovaries observed following hematoxylin and eosin staining. The control group was ovaries which were not transplanted with eGFP-labeled GCs, so different stages of follicles can be observed in the ovaries. Scale bars, $100 \mu \mathrm{m}$. eGFP, enhanced GFP; GCs, granulosa cells; SCID, severe combined immunodeficiency. 
subsequently injected into the right ovaries of the SCID mice. Ovarian tissues were harvested at 8 weeks post-transplantation, 12 tumors were formed in the injected ovaries of 22 SCID mice with no tumors formed in the uninjected ovaries of 22 SCID mice (three tumors and three control ovaries are presented in Fig. 5B). In addition, fluorescence microscopy of frozen tissue sections demonstrated that almost all tumors comprised eGFP-positive cells and that a few of follicle-like structures were observed (Fig. 5C). The presence of follicle-like structures was confirmed by histological analysis following hematoxylin and eosin staining (Fig. 5D). In addition, numerous adipocytes-like cells and some granulosa-like cells were identified in the tumors (Fig. 5D). No mass or tumor was detected in the SCID mice which were injected with cells into subcutaneous back or abdominal cavity (data not shown).

\section{Discussion}

The present study aimed to develop an improved culture medium to support GC proliferation in vitro. MEF-conditioned medium, which had commonly been used in mouse and human embryonic stem cell cultures $(24,25)$, was tested. Cells from follicular fluid could be maintained up to 14 weeks in culture (data not shown), which was similar to findings previously reported $(12,15)$. Although we tried to establish an immortal GCs cell line 20 times, only one clone was able to grow up to 130 passages without morphological changes. Because the cultured cells usually stopped proliferating eventually in the present study, a group of epithelial-like cells at passage 4 was discovered and was found to rapidly proliferate. At passage 8, a uniform cell population was obtained, which kept growing up to 130 passages without morphological changes. Cells proliferated in a stable manner, the average DT was $\sim 22 \mathrm{~h}$ and the colony formation ability was $\sim 56.3 \%$. These results indicated the presence of stable GCs cultured in vitro for over one year.

Numerous GCs, theca cells and blood cells are present in the follicular fluid of patients included in IVF programs (26). Furthermore, contamination with vaginal and ovarian surface epithelial cells commonly occurs due to transvaginal follicular aspiration (27). To confirm the identity of the cell culture established in the current study, flow cytometric analysis, immunofluorescence staining and RT-qPCR analysis were performed. The results demonstrated that GCs expressed HLA-ABC, the most important human histocompatibility antigen (28), and also mesenchymal lineage markers including CD29, CD166 and CD49f (25) but were negative for hematopoietic cell markers including CD13, CD31 and CD45 (12), which indicated that cells were of mesodermal origin (29). In addition, cells were positive for FSHR, LHR and CYP19A. For the immunofluorescence staining experiment, BMSCs were used as the negative control. It has been commonly accepted that pituitary-derived hormones, including FSH and LH, act exclusively on the gonads and are only expressed on ovary and testis gonad cells (30); however, in the last decade, whether FSHR and LHR are expressed in nongonadal tissues/cells remains a controversy. Previous studies reported extremely low levels of FSH, LH receptors in nongonadal tissues/cells $(31,32)$, including human umbilical cord and osteoclasts. Kumar (33) therefore highlighted the need for novel genetic models to investigate the extragonadal actions of FSH. Previous studies revealed no expression of FSH and LH receptors in umbilical cord and bone cells (34-36). In the present study, FSHR and LHR were not detected in BMSCs. In addition, experiments were performed where mock cells were only incubated with secondary antibodies and fresh GCs were used as a positive control. GCs are the only cell type in the female body possessing the FSHR (37). The expression of FSHR and LHR were neither observed on BMSCs nor on mock cells, which suggested that cells may be GCs. Kossowska-Tomaszczuk et al (3) revealed that long-term cultivated human GCs expressed human mesenchymal stem cell markers, including CD29, CD44, CD90, CD105, CD117 and CD166 but not CD73. Bruckova et al (15) reported that when follicular fluid was added to the culture medium, long-term cultured human GCs highly expressed human mesenchymal cell markers, including CD29, CD44, CD73, CD90 and CD166, and FSHR; however, they did not express CD31, CD34, CD49d, CD49e, CD106, CD184, CD197 or HLA-II. Furthermore, the immortalized GC line COV434 highly expresses HLA-I, slightly expresses FSHR, LHR and CD166, and does not express CD29, CD31, CD34, CD44, CD45, CD49d, CD49e, CD73, CD90, CD105, CD106 and HLA-II (15). The phenotype of the cells established in the present study was therefore similar to the GC line COV434 and the GC lines that have been previously reported.

In humans, immortalized GC lines can be established using ovarian tumor samples (COV434, KGN and HSOGT cell lines) or via gene transfection (SVOG-4o, HGL5, HO-23, GC1a, HGP53 and HGrC1 cell lines) (38). The functions of immortalized GCs, including their role in hormone secretion and their response to hormones, vary from cell to cell. For example, KGN, HGL5 and $\mathrm{HGrC1}$ have been reported to secrete estrogen and progesterone (39-41); however, COV434 and HSOGT only produce estrogen (42-44), and HO-23, HGP53 and SVOG-4o only synthesize progesterone (45-47). Furthermore, COV434, KGN, HGP53 and $\mathrm{HGrC1}$ cells respond to FSH stimulation $(41-43,47,48)$ whereas SVOG-4o cells are sensitive to LH/HCG stimulation (45). The cell lines HGL5 (39), HO-23 (46) and GCla (49) do not respond to either FSH or LH. Functional analyses of the immortalized GCs established in the present study demonstrated that intracellular cAMP accumulation could be upregulated by FSH/HCG stimulation. In addition, $\mathrm{A}_{2}$ treatment induced estradiol secretion, combined $\mathrm{A}_{2}$ and $\mathrm{Bu}_{2} \mathrm{cAMP}$ treatments significantly improved estradiol secretion, whereas $\mathrm{A}_{2}$ treatment combined with FSH/HCG did not stimulate estradiol secretion. In addition, the present study demonstrated that progesterone secretion was induced by FSH and/or HCG treatment, but not by the PKA pathway activator forskolin (50) or by $\mathrm{Bu}_{2} \mathrm{cAMP}$. These results, and the underlying mechanisms, should be further investigated in the future. FSH/HCG binding to their receptors activates the protein kinase A (PKA) pathway that stimulates cAMP accumulation $(51,52)$. Cells established in the present study may act directly on FSHR and $\mathrm{LH} / \mathrm{HCG}$ receptors which may activate the PKA pathway in order for FSH/HCG to exert their roles. However, certain other crucial factors are involved in the steroid synthesis process such as certain hormone glycosylation variants, potentiating antibodies and small molecule ligands (52), which could be further investigated in future studies. The long-term cultivated cells from the present study 
may provide a model to study the physiological mechanisms of steroidogenesis and folliculogenesis.

To determine whether the cells established in the present study could survive in SCID mice, cells were injected into SCID mice ovaries. Tumors were observed at 8 weeks post-injection. However, no tumor was observed when the same number of cells was injected subcutaneously or intraperitoneally in SCID mice (data not shown). This could be due to the blood supply in the ovaries being better compared with the other two locations or due to ovaries providing a unique environment for cell survival. In particular, this study reported that cells formed follicle-like structures. However, whether the surviving cells could respond to FSH/HCG stimulation in vivo was not investigated. In addition, the hormone levels of the tumor-bearing animals should be determined in the future.

Previous studies reported that GCs possess a multipotent differentiation capacity $(9,11,13,53)$. In the current study, cells spontaneously differentiated into adipocyte-like structures following intra-ovarian injection. The multipotent differentiation capacity of this cell line is currently being investigated.

\section{Acknowledgements}

The authors would like to thank Dr QinQjn Hong, Dr Rengfei Cai, Dr Meiting Qiu and Wei Jing of the Department of Assisted Reproduction at the Shanghai Ninth People's Hospital for their contributions to data collection and statistical analysis.

\section{Funding}

This work was supported by the National Key Research and Development Program of China (grant no. 2016YFC1101400) and the National Natural Science Foundation of China (grant no. 81771993).

\section{Availability of data and materials}

The datasets used and/or analyzed during the present study available from the corresponding author on reasonable request.

\section{Authors' contributions}

AA and WZ designed the study, interpreted the results, wrote the manuscript and approved the final form of the manuscript. AA, ZT and YL conducted the experiments. SY performed the statistical analysis. BL, XW and $\mathrm{HH}$ participated in the data collection. YC participated in study design, data interpretation, critical revision and approved the final form of the manuscript. All authors read and approved the final manuscript.

\section{Ethics approval and consent to participate}

The study was approved by the Ethics Committee of the Shanghai Ninth People's Hospital affiliated with Shanghai Jiao Tong University School of Medicine. Written informed consent was provided by all participants prior to the study. Animal studies were approved by the Animal Experimentation Ethics Committee of the Shanghai Ninth People's Hospital affiliated with Shanghai Jiao Tong University School of Medicine.

\section{Patient consent for publication}

All patients provided informed consent for the publication of their clinical data.

\section{Competing interest}

The authors declare that no conflicts of interest to declare.

\section{References}

1. Senbon S, Hirao Y and Miyano T: Interactions between the oocyte and surrounding somatic cells in follicular development: Lessons from in vitro culture. J Reprod Dev 49: 259-269, 2003.

2. Dzafic E, Stimpfel M and Virant-Klun I: Plasticity of granulosa cells: On the crossroad of stemness and transdifferentiation potential. J Assist Reprod Genet 30: 1255-1261, 2013.

3. Kossowska-Tomaszczuk K, De Geyter C, De Geyter M, Martin I, Holzgreve W, Scherberich A and Zhang H: The multipotency of luteinizing granulosa cells collected from mature ovarian follicles. Stem Cells 27: 210-219, 2009.

4. Gougeon A: Regulation of ovarian follicular development in primates: Facts and hypotheses. Endocr Rev 17: 121-155, 1996.

5. Niswender GD, Juengel JL, Silva PJ, Rollyson MK and McIntush EW: Mechanisms controlling the function and the life span of the corpus luteum. Physiol Rev 80: 1-29, 2000.

6. Lavranos TC, Rodgers HF, Bertoncello I and Rodgers RJ: Anchorage-independent culture of bovine granulosa cells: The effects of basic fibroblast growth factor and dibutyryl cAMP on cell division and differentiation. Exp Cell Res 211: 245-251, 1994

7. Van Deerlin PG, Cekleniak N, Coutifaris C, Boyd J and Strauss JF 3rd: Evidence for the oligoclonal origin of the granulosa cell population of the mature human follicle. J Clin Endocrinol Metab 82: 3019-3024, 1997.

8. Lavranos TC, Mathis JM, Latham SE, Kalionis B, Shay JW and Rodgers RJ: Evidence for ovarian granulosa stem cells: Telomerase activity and localization of the telomerase ribonucleic acid component in bovine ovarian follicles. Biol Reprod 61: 358-366, 1999.

9. Bukovsky A, Caudle MR and Svetlikova M: Steroid-mediated differentiation of neural/neuronal cells from epithelial ovarian precursors in vitro. Cell Cycle 7: 3577-3583, 2008.

10. Bukovsky A, Gupta SK, Virant-Klun I, Upadhyaya NB, Copas P, Van Meter SE, Svetlikova M, Ayala ME and Dominguez R: Study origin of germ cells and formation of new primary follicles in adult human and rat ovaries. Methods Mol Biol 450: 233-265, 2008.

11. Virant-Klun I, Zech N, Rozman P, Vogler A, Cvjeticanin B, Klemenc P, Malicev E and Meden-Vrtovec H: Putative stem cells with an embryonic character isolated from the ovarian surface epithelium of women with no naturally present follicles and oocytes. Differentiation 76: 843-856, 2008.

12. Varras M, Griva T, Kalles V, Akrivis C and Paparisteidis N: Markers of stem cells in human ovarian granulosa cells: Is there a clinical significance in ART? J Ovarian Res 5: 36, 2012.

13. Kossowska-Tomaszczuk K and De Geyter C: Cells with stem cell characteristics in somatic compartments of the ovary. Biomed Res Int 2013: 310859, 2013.

14. Kossowska-Tomaszczuk K, Pelczar P, Güven S, Kowalski J, Volpi E, De Geyter C and Scherberich A: A novel three-dimensional culture system allows prolonged culture of functional human granulosa cells and mimics the ovarian environment. Tissue Eng Part A 16: 2063-2073, 2010.

15. Bruckova L, Soukup T, Visek B, Moos J, Moosova M, Pavelkova J, Rezabek K, Kucerova L, Micuda S, Brcakova E and Mokry J: Proliferative potential and phenotypic analysis of long-term cultivated human granulosa cells initiated by addition of follicular fluid. J Assist Reprod Genet 28: 939-950, 2011.

16. Evans MJ and Kaufman MH: Establishment in culture of pluripotential cells from mouse embryos. Nature 292: 154-156, 1981.

17. Lim JW and Bodnar A: Proteome analysis of conditioned medium from mouse embryonic fibroblast feeder layers which support the growth of human embryonic stem cells. Proteomics 2: 1187-1203, 2002.

18. Shi YT, Huang YZ, Tang F and Chu JX: Mouse embryonic stem cell-derived feeder cells support the growth of their own mouse embryonic stem cells. Cell Biol Int 30: 1041-1047, 2006. 
19. Kuang Y, Chen Q, Fu Y, Wang Y, Hong Q, Lyu Q, Ai A and Shoham Z: Medroxyprogesterone acetate is an effective oral alternative for preventing premature luteinizing hormone surges in women undergoing controlled ovarian hyperstimulation for in vitro fertilization. Fertil Steril 104: 62-70 e63, 2015.

20. Zhang L, He A, Yin Z, Yu Z, Luo X, Liu W, Zhang W, Cao Y, Liu Y and Zhou G: Regeneration of human-ear-shaped cartilage by co-culturing human microtia chondrocytes with BMSCs. Biomaterials 35: 4878-4887, 2014.

21. Chen Y, Ai A, Tang ZY, Zhou GD, Liu W, Cao Y and Zhang WJ: Mesenchymal-like stem cells derived from human parthenogenetic embryonic stem cells. Stem Cells Dev 21: 143-151, 2012.

22. Baroffio A, Dupin E and Le Douarin NM: Clone-forming ability and differentiation potential of migratory neural crest cells. Proc Natl Acad Sci USA 85: 5325-5329, 1988.

23. Gan Y, Dai K, Zhang P, Tang T, Zhu Z and Lu J: The clinical use of enriched bone marrow stem cells combined with porous beta-tricalcium phosphate in posterior spinal fusion. Biomaterials 29: 3973-3982, 2008

24. Xu C, Inokuma MS, Denham J, Golds K, Kundu P, Gold JD and Carpenter MK: Feeder-free growth of undifferentiated human embryonic stem cells. Nat Biotechnol 19: 971-974. 2001.

25. Liu L, Peng Z, Xu Z, Huang H and Wei X: Mouse embryonic fibroblast (MEF)/BMP4-conditioned medium enhanced multipotency of human dental pulp cells. J Mol Histol 49: 17-26, 2018

26. Ferrero H, Delgado-Rosas F, Garcia-Pascual CM, Monterde M, Zimmermann RC, Simón C, Pellicer A and Gómez R: Efficiency and purity provided by the existing methods for the isolation of luteinized granulosa cells: A comparative study. Hum Reprod 27: 1781-1789, 2012.

27. Beckmann MW, Polacek D, Seung L and Schreiber JR: Human ovarian granulosa cell culture: Determination of blood cell contamination and evaluation of possible culture purification steps. Fertil Steril 56: 881-887, 1991.

28. Thorsby E: A short history of HLA. Tissue Antigens 74: 101-116, 2009.

29. Dzafic E, Stimpfel M, Novakovic S, Cerkovnik P and Virant-Klun I: Expression of mesenchymal stem cells-related genes and plasticity of aspirated follicular cells obtained from infertile women. Biomed Res Int 2014: 508216, 2014.

30. Rice S, Elia A, Jawad Z, Pellatt L and Mason HD: Metformin inhibits follicle-stimulating hormone (FSH) action in human granulosa cells: Relevance to polycystic ovary syndrome. J Clin Endocrinol Metab 98: E1491-E1500, 2013.

31. James K, Bhartiya D, Ganguly R, Kaushik A, Gala K, Singh P and Metkari SM: Gonadotropin and steroid hormones regulate pluripotent very small embryonic-like stem cells in adult mouse uterine endometrium. J Ovarian Res 11: 83, 2018.

32. Kumar TR: Extragonadal FSH receptor: Is it real? Biol Reprod 91 99, 2014.

33. Kumar TR: Extragonadal actions of FSH: A critical need for novel genetic models. Endocrinology 159: 2-8, 2018.

34. Allan CM, Kalak R, Dunstan CR, McTavish KJ, Zhou H, Handelsman DJ and Seibel MJ: Follicle-stimulating hormone increases bone mass in female mice. Proc Natl Acad Sci USA 107: 22629-22634, 2010.

35. Stelmaszewska J, Chrusciel M, Doroszko M, Akerfelt M, Ponikwicka-Tyszko D, Nees M, Frentsch M, Li X, Kero J, Huhtaniemi I, et al: Revisiting the expression and function of follicle-stimulation hormone receptor in human umbilical vein endothelial cells. Sci Rep 6: 37095, 2016

36. Davis MR and Summers KM: Structure and function of the mammalian fibrillin gene family: Implications for human connective tissue diseases. Mol Genet Metab 107: 635-647, 2012

37. Méduri G, Charnaux N, Driancourt MA, Combettes L, Granet P, Vannier B, Loosfelt $\mathrm{H}$ and Milgrom E: Follicle-stimulating hormone receptors in oocytes. J Clin Endocrinol Metab 87: 2266-2276, 2002.

38. Havelock JC, Rainey WE and Carr BR: Ovarian granulosa cell lines. Mol Cell Endocrinol 228: 67-78, 2004.

39. Rainey WH, Sawetawan C, Shay JW, Michael MD, Mathis JM, Kutteh W, Byrd W and Carr BR: Transformation of human granulosa cells with the E6 and E7 regions of human papillomavirus. J Clin Endocrinol Metab 78: 705-710, 1994.
40. Tsutsumi R, Hiroi H, Momoeda M, Hosokawa Y, Nakazawa F, Koizumi M, Yano T, Tsutsumi $\mathrm{O}$ and Taketani Y: Inhibitory effects of cholesterol sulfate on progesterone production in human granulosa-like tumor cell line, KGN. Endocr J 55: $575-581,2008$

41. Bayasula, Iwase A, Kiyono T, Takikawa S, Goto M, Nakamura T, Nagatomo Y, Nakahara T, Kotani T, Kobayashi H, et al: Establishment of a human nonluteinized granulosa cell line that transitions from the gonadotropin-independent to the gonadotropin-dependent status. Endocrinology 153: 2851-2860, 2012.

42. van den Berg-Bakker CA, Hagemeijer A, Franken-Postma EM, Smit VT, Kuppen PJ, van Ravenswaay Claasen $\mathrm{HH}$, Cornelisse CJ and Schrier PI: Establishment and characterization of 7 ovarian carcinoma cell lines and one granulosa tumor cell line: Growth features and cytogenetics. Int J Cancer 53: 613-620, 1993

43. Zhang H, Vollmer M, De Geyter M, Litzistorf Y, Ladewig A, Dürrenberger M, Guggenheim R, Miny P, Holzgreve W and De Geyter C: Characterization of an immortalized human granulosa cell line (COV434). Mol Hum Reprod 6: 146-153, 2000.

44. Kondo H, Kiguchi K, Okamura A, Okuma Y, Iida T, Kobayashi Y, Takagi M, Ishizuka B and Ishiwata I: Establishment and characterization of a human ovarian granulosa tumor cell line (HSOGT). Hum Cell 16: 123-129, 2003.

45. Lie BL, Leung E, Leung PC and Auersperg N: Long-term growth and steroidogenic potential of human granulosa-lutein cells immortalized with SV40 large T antigen. Mol Cell Endocrinol 120: 169-176, 1996.

46. Hosokawa K, Dantes A, Schere-Levy C, Barash A, Yoshida Y, Kotsuji F, Vlodavsky I and Amsterdam A: Induction of Ad4BP/SF-1, steroidogenic acute regulatory protein, and cytochrome P450scc enzyme system expression in newly established human granulosa cell lines. Endocrinology 139: 4679-4687, 1998.

47. Tajima K, Hosokawa K, Yoshida Y, Dantes A, Sasson R, Kotsuji F and Amsterdam A: Establishment of FSH-responsive cell lines by transfection of pre-ovulatory human granulosa cells with mutated p53 (p53val135) and Ha-ras genes. Mol Hum Reprod 8: 48-57, 2002.

48. Nishi Y, Yanase T, Mu Y, Oba K, Ichino I, Saito M, Nomura M, Mukasa C, Okabe T, Goto K, et al: Establishment and characterization of a steroidogenic human granulosa-like tumor cell line, $\mathrm{KGN}$, that expresses functional follicle-stimulating hormone receptor. Endocrinology 142: 437-445, 2001.

49. Okamura $\mathrm{H}$, Katabuchi $\mathrm{H}$ and Ohba T: What we have learned from isolated cells from human ovary? Mol Cell Endocrinol 202: 37-45, 2003.

50. Nguyen TD, Filliatreau L, Klett D and Combarnous Y: Comparative effects of sub-stimulating concentrations of non-human versus human Luteinizing Hormones $(\mathrm{LH})$ or chorionic gonadotropins (CG) on adenylate cyclase activation by forskolin in MLTC cells. Gen Comp Endocrinol 261: 23-30, 2018.

51. Reed BG and Carr BR: The Normal Menstrual Cycle and the Control of Ovulation. In: Endotext [Internet]. Feingold KR, Anawalt B, Boyce A, et al (eds.). MDText.com, South Dartmouth, MA, 2000-

52. Gloaguen P, Crépieux P, Heitzler D, Poupon A and Reiter E: Mapping the follicle-stimulating hormone-induced signaling networks. Front Endocrinol (Lausanne) 2: 45, 2011.

53. Virant-Klun I, Rozman P, Cvjeticanin B, Vrtacnik-Bokal E, Novakovic S, Rülicke T, Dove P and Meden-Vrtovec H: Parthenogenetic embryo-like structures in the human ovarian surface epithelium cell culture in postmenopausal women with no naturally present follicles and oocytes. Stem Cells Dev 18: 137-149, 2009.

This work is licensed under a Creative Commons Attribution-NonCommercial-NoDerivatives 4.0 International (CC BY-NC-ND 4.0) License. 